\title{
PROTOTIPE ALAT MONITORING KESEHATAN JANTUNG BERBASIS IoT
}

\author{
Ridho Surya Kusuma, Faisal Akbaruddin, Umi Fadlilah \\ Program studi Teknik Elektro \\ Universitas Muhammadiyah Surakarta \\ D400150096@student.ums.ac.id, \\ D400150110@student.ums.ac.id \\ umi.fadlilah@ums.ac.id
}

\author{
Mey Pamungkasty \\ Ilmu Kesehatan \\ Universitas Muhammadiyah Surakarta \\ J2101150106@student.ums.ac.id
}

\begin{abstract}
Abstraksi-Kesehatan jantung merupakan investasi jangka panjang untuk keberlangsungan hidup. Oleh karena itu untuk mewujudkan jantung sehat dan terhindar dari penyakit kardiovaskular ini, dibuatlah sebuah inovasi alat prototipe monitoring kesehatan jantung dengan sistem online. Sistem monitoring ini mengkombinasikan antara sistem pakar VCIRS (Variable Centered Intelligence Rule System ), pengukuran detak jantung BPM (beat per minute), dan IoT (Internet of Things) yang bertujuan untuk memonitoring kesehatan jantung dan mendeteksi penyakit jantung secara dini serta dilakukan mandiri. Keluaran dari sistem ini adalah pernyataan bahwa pengguna dalam kondisi jantung sehat atau menderita gejala penyakit jantung kemudian dilanjutkan dengan analisa dari pengguna dengan memilih gejala sesuai yang form yang disediakan. Berdasarkan pengujian dan analisa sistem bahwa prototipe alat monitoring kesehatan jantung telah mampu menganalisa serta berjalan dengan baik. Hasil dari analisa alat ini dapat dilihat secara online di situs website.
\end{abstract}

Katakunci-BPM, VCIRS, Internet Of Things, Sensor Pulse Heart

\section{PENDAHULUAN}

Berdasarkan hasil Survei Kesehatan Rumah Tangga Nasional (SKRTN), dalam 10 tahun terakhir angka kematian di Indonesia akibat Penyakit jantung koroner cenderung mengalami peningkatan. Pada tahun 1991, angka kematian akibat Penyakit jantung koroner adalah $16 \%$. Kemudian di tahun 2001 angka tersebut melonjak menjadi $26,4 \%$. diperkirakan mencapai 53,5 per 100.000 penduduk di Indonesia (http://www.tribunnews.com, 2012).

Berdasarkan data di atas dipaparkan bahwa gangguan pada jantung meningkat dan masyarkat masih rendah sekali kesadarannya tentang kesehatan jantung. Hal ini menjadi sangat penting karena memberikan informasi detak jantung yang sehat serta menentukan baik buruknya keadaan jantung pada saat beraktifitas dan tidak beraktivitas. Jadi penulis berinisiatif, untuk merancang suatu alat yang memungkikan pengguna dapat melakukan perawatan kesehatan jantung. Alat ini berbasis mikrokontroler Wemos D1R1 mempunyai keluaran berupa BPM detak jantung di running text pada layar liquid crystal display $(L C D)$ alat dan website server. Pada bagian website server pengguna juga dapat melakukan diagnosa gejala penyakit jantung menggunakan sistem VCIRS.

\section{Metode PenELITIAN}

Perangkat keras yang digunakan dalam alat ini adalah sensor Easy Pulse Heart Sensor, mikrokontroler Wemos D1R1, Baterai $12 \mathrm{v}$, Box, dan $L C D$. Perangkat lunak yang digunakan untuk pembangunan alat terdiri atas komputer dengan sistem operasi Windows/Linux, kompailer bahasa $\mathrm{C}$ dan Arduino IDE. Pengembangan alat mempunyai empat tahapan seperti yang ditunjukkan pada Gambar 1 .

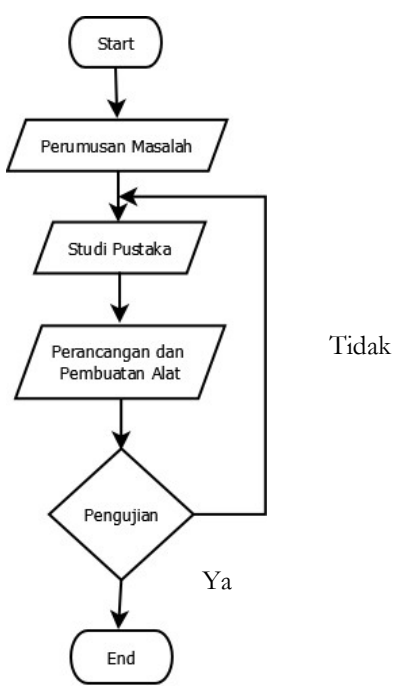

Gambar 1. Alur pelaksanaan penelitian 


\section{a. Perumusan Masalah}

Kegiatan Perumusan Masalah dilakukan dengan bertujuan untuk mencari permasalahan-permasalahan tentang kesehatan jantung meliputi nilai BPM jantung sehat dan tidak sehat, cara mendeteksi dini jantung yang tidak sehat dengan jumlah detak jantung permenit. Pada dasarnya nilai BPM jantung sehat berkisar antara 60-100 BPM.

Studi Pustaka dilakukan dengan mencari bahan penunjang dari jurnal ilmiah, Artikel publikasi, maupun makalah yang mempunyai keterkaitan dengan penelitian yang dilakukan. Beberapa bahan yang dicari dalam studi pustaka ini yaitu :

\section{a) Organ Jantung}

Jantung merupakan salah satu organ vital manusia dengan besar satu kepalan tangan dan terletak di rongga dada sebelah kiri. Jantung terbagi menjadi 4 ruang yaitu 2 atrium (sering disebut serambi kiri dan kanan) dan 2 bilik (bilik kiri dan kanan).

Penyakit jantung merupakan sebutan untuk segala macam penyakit berbeda. Ada beberapa jenis penyakit jantung seperti (Coronary heart disease), diakibatkan pengendapan atheroma di dalam dinding ateri yang menyuplai miokardium. (Ischaemic heart disease), penyakit yang disebabkan berkurangnya suplai darah ke jantung. Penyakit kardiovaskular(Cardiovascular disease), penyakit yang menyerang jantung/ saluran darah (arteri dan vena). (Pulmonary heart disease), kegagalan pada ventrikel kanan jantung.

\section{b) Sistem pakar}

Sistem pakar adalah suatu program komputer yang mengandung pengetahuan dari satu atau lebih pakar manusia mengenai suatu bidang spesifik. Jenis program ini pertama kali dikembangkan oleh periset kecerdasan buatan pada tahun 1960-an dan 1970-an dan diterapkan secara komersial selama 1980-an. Bentuk umum sistem pakar adalah suatu program yang dibuat berdasarkan suatu set aturan yang menganalisis informasi (biasanya diberikan oleh pengguna suatu sistem) mengenai suatu kelas masalah spesifik serta analisis matematis dari masalah tersebut. Tergantung dari desainnya, sistem pakar juga mampu merekomendasikan suatu rangkaian tindakan pengguna untuk dapat menerapkan koreksi. Sistem ini memanfaatkan kapabilitas penalaran untuk mencapai suatu simpulan [3].

c) Arduino

Arduino adalah kit elektronik atau papan rangkaian elektronik open source yang di dalamnya terdapat komponen utama sebuah chip mikrokontroler dengan jenis AVR (Automatic Voltage Regulator) dari perusahaan Atmel.

Mikrokontroler tersebut berupa chip atau IC (integrated circuit)yang bisa diprogram menggunakan komputer. Tujuan menanamkan program pada mikrokontroler adalah agar rangkaian elektronik dapat membaca masukan, memproses masukan tersebut dan kemudian menghasilkan keluaran sesuai yang diinginkan. Jadi mikrokontroler bertugas sebagai "otak"e yang mengendalikan masukan, proses dan keluaran sebuah rangkaian elektronik. komponen utama Arduin oadalah mikrokontroler, maka Arduino pun dapat diprogram menggunakan komputer sesuai kebutuhan.

\section{d) Easy Pulse Plugin Heart Rate Sensor}

Easy Pulse Plugin adalah sensor detak jantung yang bekerja menggunakan prinsip photoplethysmography(PPG), yaitu metode non-invasive untuk mengukur detak jantung (kardiovaskular) dengan cara mendeteksi volume aliran darah didalam nadi yang sangat dekat dengan kulit. Sensor ini menggunakan IR LED dan photodetector, dimana denyut nadi dijari anda akan mempengaruhi aliran cahaya dari IR LED ke photodetector, perubahan2 ini kemudian dikonversi, difilter dan di perkuat oleh modul sensor untuk kemudian diproses oleh Arduino atau minsys lainnya.[4]

\section{e) Website Server}

Server atau Web server adalah sebuah situs online yang memberikan layanan berbasis data dan berfungsi menerima permintaan dari HTTP atau HTTPS dan untuk mengirimkan kembali yang hasilnya dalam bentuk beberapa halaman web dan pada umumnya akan berbentuk dokumen HTML.

\section{f) Nilai BPM}

Nilai BPM manusia normal berkisar antara 60-100BPM, untuk nilai 50-59 atau 101-120 BPM adalah kondisi dimana jantung kurang sehat, maka dari itu perlu dilakukannya pengukuran jantung secara intensif selama kurun waktu 1 minggu, lalu segera untuk mengecek kesehatan jantung. Jika nilai di bawah 50 atau di atas 120 maka harus segera ditangani oleh dokter atau tenaga medis.

\section{A. Perancangan dan Pembuatan Alat}

Kit modul dan komponen yang sudah didapatkan selanjutnya dirangkai sesuai dengan rancangan yang diinginkan. Pada perancangan juga ditambahkan komponen penunjang lainya yaitu DC step down, LED (Light Emitting Diode) indikator, push button, dan tombol saklar.

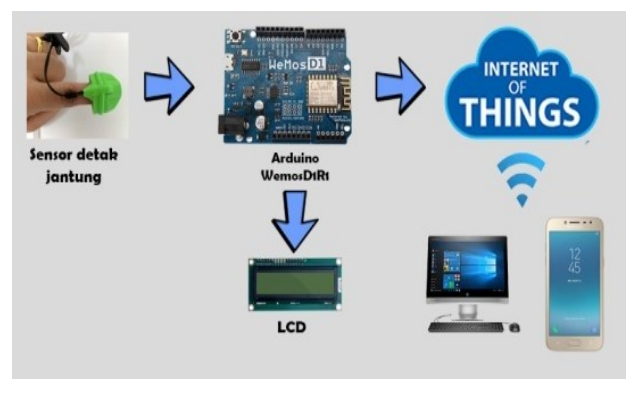

Gambar 2. Skema Penerapan alat

Alat ini dibuat dengan konsep minimalis, efisien, dan mudah digunakan. Cara penggunaanya hanya dengan menekan saklar on, pengguna meletakkan jari ke sensor pada alat tersebut, data detak jantung akan terlihat di $L C D$ dan akan 
langsung mengirim data ke server agar bisa disimpan dan dilihat secara online. Cara kerja dari alat ini adalah :

a) Sensor detak jantung terhubung ke Arduino WemosD1R1

b) Sensor detak jantung mendeteksi detak jantung melalui ujung jari.

c) Nilai jumlah detak jantung yang terditeksi diubah ke digital melalui Analog Digital Converter pada Arduino, selanjutnya ditampilkan ke layar LCD.

d) Data nilai numlah detak jantung dikirim dan disimpan ke server.

e) Server menampilkan nilai jumlah detak jantung yang diterima pada halaman website yang telah disediakan.

\section{B. Pengujian Alat}

\section{1) Pengujian sensor}

Pengujian sensor dilakukan untuk memberikan kepresisian sensor dapat bekerja dengan baik. Cara pengujian sensor dengan meletakkan ujung salah satu jari ke sensor selanjutnya dicermati apakah sensor mampu merekam data detak jantung.

\section{2) Pengujian sofware}

Komponen yang sudah dirangkai kemudian diuji kepada pengguna untuk pengambilan data. Nilai detak jantung (BPM) dari pengguna akan dijadikan parameter apakah jantung pengguna dalam kategori sehat atau tidak.

\section{3) Pengujian $W E B$}

Data BPM dari sensor ke ardunio selanjutnya diteruskan secara wireless ke big data server. Pengguna dapat melihat hasilnya melalui situs yang disediakan secara online, jika nilai BPM dari sensor cendrung menurun maka akan ditampilkan pertanyaan diagnosa penyakit jantung.

4) Pengujian dengan membandingan dengan alat yang sejenis

Pengujian ini dilakukan untuk mengetahui nilai keakuratan dan kepresisian nilai BPM. Metode yang digunakan adalah membandingkan nilai BPM alat dengan alat oximeter yang sudah ada di pasaran. Pengujian ini berfungsi sebagai kalibrasi alat.

\section{HASIL DAN PEMBAHASAN}

\section{A. Sistem Logika}

Perancangan ini menggunakan kaidah produksi dalam bentuk pernyataan JIKA [premis] MAKA [konklusi]. Dalam hal ini premis adalah gejala sedangkan konklusi adalah jenis penyakit jantung, sehingga bentuk pernyataannya adalah JIKA [gejala] MAKA [jenis penyakit jantung]. Adapun bentuk pernyataan adalah :

JIKA [gejala 1]

DAN [gejala 2]

DAN [gejala 3] MAKA [penyakit]

Berikut kaidah produksi / aturan dari penyakit jantung :

\section{Kaidah 1 : JIKA LB0000001}

DAN LB0000002

DAN LB0000003

DAN LB0000004

DAN LB0000005

DAN LB0000010

DAN LB0000011

DAN LB0000012

DAN LB0000013

MAKA penyakit jantung Sindrom Koroner Akut.

\section{B. Alat}

Hasil dari tampilan fisik dapat dilihat pada gambar. Pada tampilan luar alat ini menggunakan box sebagai wadahnya, dan terdapat LED indikator, senor yang berada di luar, serta keypad. Dari hasil percobaan, jika saklar dihidupkan maka layar LCD dan LED indikator pada keypad menyala seperti pada Gambar 3.

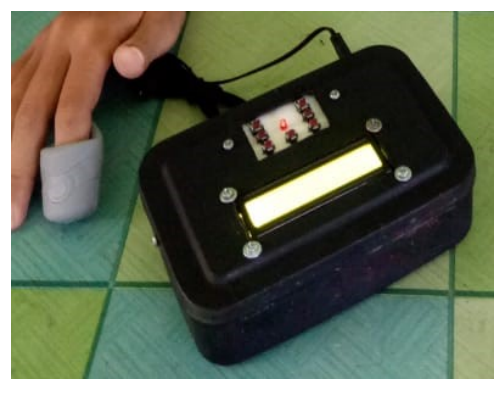

Gambar 3. Alat yang dikembangkan

Jika pengguna ingin mengecek kesehatan jantung dengan BPM dari alat ini, pertama-tama menghidupkan alat terlebih dahulu dengan menghidupkan saklar lalu LCD dan LED indikator akan menyala. Selanjutnya pengguna meletakkan ujung salah satu jari ke dalam sensor dan alat akan menghitung jumlah detak jantung pengguna. Jika data ingin disimpan secara online tinggal menekan tombol send.

\section{Data detakjantung sebagai indikator}

Untuk mengetahui kesehatan kesehatan jantung dapat dilihat dari nilai BPM pengguna, dengan asumsi detak jantung normal pada orang dewasa saat beristirahat adalah 60 sampai 100 kali per menit. Tidak terkena kelainan takikardia (memiliki denyut jantung rata-rata lebih besar dari 100 BPM), atau bradikardia (memiliki denyut jantung rata-rata lebih kecil dari 60 BPM (sumber).

Pada penelitian ini dilakukan 10 pengujian dari 10 pengguna yang berbeda di puskesmas Andong Surakarta terlihat pada Tabel 1 dan perbandingan hasil dengan alat Oximeter yang sudah ada di pasaran serta pengukuran yang direkam oleh website server di Gambar 4. Pada hasil 
pengamatan, jika dalam detak jantung berada di luar ambang normal (BPM 60-100) dan beberapa pemeriksaan tetap sama maka sistem pakar akan berjalan dan memberikan beberapa pertanyaan.

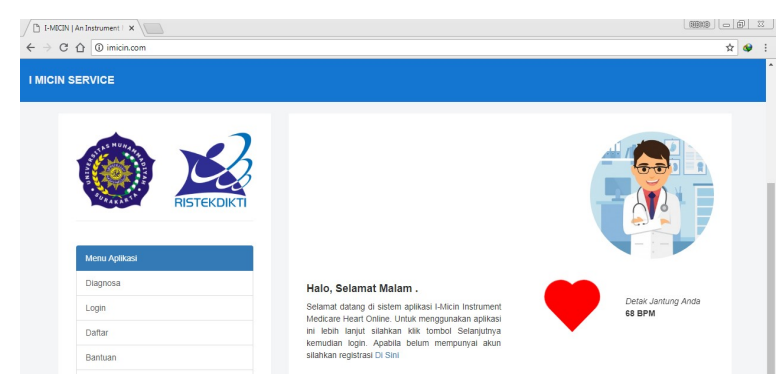

Gambar 4. Tampilan rekaman nilai bpm yang dikirim ke website server

Pengujian pertama, menggunakan metode membandingkan dengan alat sejenis yang sudah terdapat dipasaran untuk menguji keakuratan atau kalibrasi pada alat yang dibuat. Alat yang digunakan untuk kalibrasi yaitu Pulse Oximeter yang sudah ada dipasaran. Hasil yang didapatkan pada pengujian seperti Tabel 1. dapat dilihat bahwa alat yang dibuat dengan Pulse Oximeter yang terdapat dipasaran memiliki tingkat keakuratan yang sama. Nilai BPM yang terditeksi pada kedua alat terebut memiliki nilai error $0.1 \%$.

Pengujian yang kedua, alat yang sudah dibuat diuji secara langsung dengan alat oximeter kepada 10 responden untuk mencari selisih nilai error, dengan mendeteksi jumlah detak jantung per menit atau BPM. Hasil yang didapatkan alat berhasil menampilkan hasil pengujian nilai BPM seperti pada Tabel 2. dengan waktu yang relatif cepat.

TABEL I. HASIL PENGUJIAN DENGAN OXIMETER

\begin{tabular}{|c|c|c|}
\hline No & $\begin{array}{c}\text { Nama } \\
\text { Responden }\end{array}$ & $\begin{array}{c}\text { Hasil pengukuran } \\
\text { (BPM) }\end{array}$ \\
\hline 1 & Tn. D & 52 \\
\hline 2 & Ny. A & 57 \\
\hline 3 & Nn. S & 47 \\
\hline 4 & Nn. Y & 103 \\
\hline 5 & Nn. M & 67 \\
\hline 6 & Nn. K & 56 \\
\hline 7 & Nn. E & 89 \\
\hline 8 & Nn.Y & 90 \\
\hline 9 & Sdr. A & 69 \\
\hline 10 & Nn.A & 132 \\
\hline
\end{tabular}

TABEL II. HASIL PENGUJIAN PUSKeSMAS

\begin{tabular}{|l|c|c|c|}
\hline No & $\begin{array}{c}\text { Jenis } \\
\text { Kelamin }\end{array}$ & Data Alat (BPM) & Data Alat Oximeter (BPM) \\
\hline 1 & L & 76 & 76 \\
\hline 2 & L & 91 & 91 \\
\hline 3 & L & 58 & 59 \\
\hline 4 & L & 79 & 78 \\
\hline 5 & L & 92 & 93 \\
\hline 6 & L & 67 & 67 \\
\hline 7 & L & 75 & 76 \\
\hline 8 & P & 80 & 81 \\
\hline 9 & P & 69 & 68 \\
\hline 10 & P & 98 & 99 \\
\hline
\end{tabular}

\section{Metode sistem pakar VCIRS}

Pengujian dilakukan dengan metode forward chaining yaitu memilih pertanyaan gejala pada menu diagnosa penyakit oleh pengguna. Dengan cara memberi centang pada checkbox masing-masing pertanyaan lalu membandingkan hasil dari sistem pakar dengan rancangan rule. Selanjutnya, sesuai dari pengguna akan memilih gejala yang dirasakan dari Gambar 5 dan hasil diagnosa melalui websiteserver yang ditampilkan pada Gambar 6 .

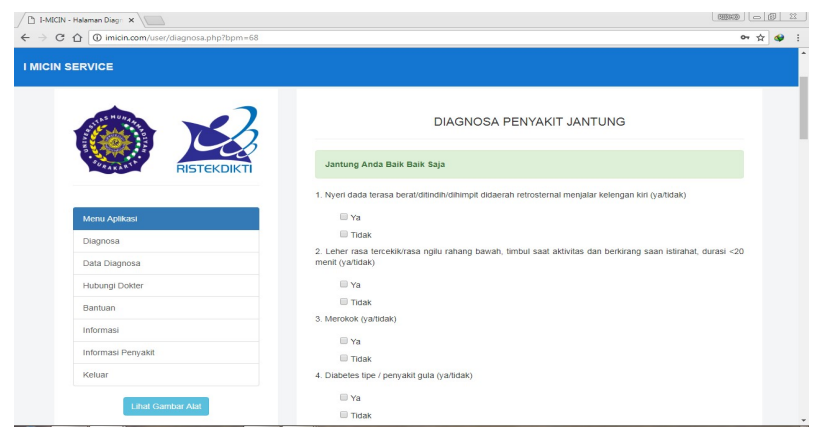

Gambar 5. Pertanyaan diagnosa penyakit jantung.

DATA DIAGNOSA PENYAKIT ANDA

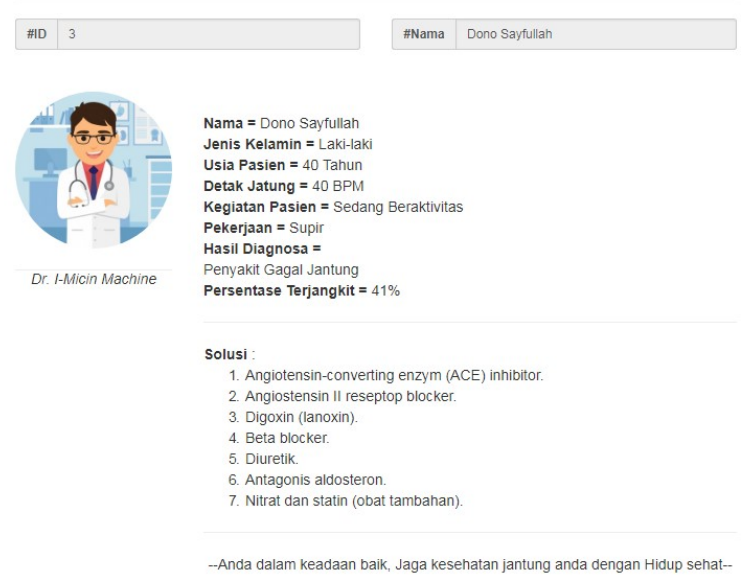

Gambar 6. Hasil diagnosa penyakit jantung.

Berikut adalah dua contoh percobaan diagnosa perempuan dan laki-laki dengan cara manual :

\section{Percobaan diagnosa Nn.S (BPM 47)}

Gejala yang dirasakan :

1) Kebiruan dikulit

2) Berkurang kemampuan aktivitas

3) sesak napas, tidak mendadak

4) kesulitan menyusui / minum

5) berat badan rendah.

Perhitungan manual sebagai berikut dapat dilihat pada Tabel 3. 
Berdasarkan Tabel 3, nilai persentase yang paling besar PJB yaitu sebesar 85\%, sehingga kemungkinan terserang "Penyakit Jantung Bawaan Sianotik".

\section{Percobaan diagnosa Tn.D (BPM 52) Gejala yang dirasakan :}

1) Nyeri dada terasa berat

2) Merokok

3) Hipertensi/tekanan darah tinggi

4) Kadang berkeringat dingin dan lemas saat aktivitas

5) Kadang berkeringat dingin dan pingsan

6) Denyut jantung tidak teratur

7) Kelelahan dan lemas

Perhitungan manual sebagai berikut dapat dilihat pada Tabel 4.

TABEL III. Perhitungan MANUAL Nn.S (BPM 47)

\begin{tabular}{|l|c|c|c|c|}
\hline \multirow{2}{*}{ Gejala } & \multicolumn{4}{|c|}{ Penyakit } \\
\cline { 2 - 5 } & ACS & CHF & RF & PJB \\
\hline Kebiruan dikulit & & & & $40 \%$ \\
\hline $\begin{array}{l}\text { Berkurang } \\
\text { kemampuan aktivitas }\end{array}$ & & $12 \%$ & & \\
\hline $\begin{array}{l}\text { Sesak napas, tidak } \\
\text { mendadak }\end{array}$ & & & & $15 \%$ \\
\hline $\begin{array}{l}\text { Kesulitan } \\
\text { menyusui/minum }\end{array}$ & & & & $15 \%$ \\
\hline Berat badan rendah & & $12 \%$ & - & $85 \%$ \\
\hline \multicolumn{1}{|c|}{ TOTAL } & - & & & $15 \%$ \\
\hline
\end{tabular}

TABEL IV. Perhitungan Manual Tn. D

\begin{tabular}{|l|c|c|c|c|}
\hline \multirow{2}{*}{ Gejala } & \multicolumn{4}{|c|}{ Penyakit } \\
\cline { 2 - 5 } & ACS & CHF & RF & PJB \\
\hline $\begin{array}{l}\text { Nyeri dada terasa } \\
\text { berat }\end{array}$ & $14 \%$ & & & \\
\hline Merokok & $10 \%$ & & & \\
\hline $\begin{array}{l}\text { Hipertensi/Tekanan } \\
\text { darah tinggi }\end{array}$ & $13 \%$ & & & \\
\hline $\begin{array}{l}\text { Kadang } \\
\text { berkeringat dingin } \\
\text { dan lemas saat } \\
\text { aktivitas }\end{array}$ & $10 \%$ & & & \\
\hline $\begin{array}{l}\text { Kadang } \\
\text { berkeringat dingin } \\
\text { dan pingsan }\end{array}$ & $10 \%$ & $7 \% \%$ & & \\
\hline $\begin{array}{l}\text { Denyut jantung } \\
\text { tidak teratur }\end{array}$ & & $5 \%$ & & \\
\hline $\begin{array}{l}\text { Kelelahan dan } \\
\text { lemas }\end{array}$ & & $12 \%$ & - & \\
\hline \multicolumn{1}{|c|}{ TOTAL } & $57 \%$ & & & \\
\hline
\end{tabular}

Berdasarkan Tabel 5, nilai persentase yang paling besar ACS yaitu sebesar 57\%, sehingga kemungkinan terserang "Penyakit Sindrom Koroner Akut".

Data sistem pakar telah banyak dipublikasikan pada berbagai jurnal ilmiah. Pada beberapa peneliatian terdahulu seperti Sri, Nurul, dan Fadilla disebutkan bahwa proses pendeteksian penyakit kardiovaskular menggunakan sistem pakar dengan metode VCIRS, ternyata mampu mendeteksi penyakit yang diderita seperti pada Tabel 4 dan Tabel 5 . Kemudian pada Gambar 5 adalah inovasi sistem pakar yang berbasis online sehingga memungkikan pengguna atau pasien dapat melihat hasil diagnosa atau suspect secara realtime, sehingga nantinya riwayat gejala penyakit pasien dapat diunduh serta dilihat kapan pun dan dimana pun.

\section{KESIMPULAN}

Berdasarkan dari penelitian yang sudah dilakukan dapat disimpulkan bahwa alat deteksi penyakit jantung dapat mendeteksi penyakit kardiovaskular secara dini, dengan menggunakan tolak ukur dari nilai BPM pengguna. Selain dapat menditeksi nilai BPM, alat ini menggunakan sistem pakar Variable Centered Intelligent Rule Systems yang memberikan analisis secara tepat terhadap jenis dan presentase terjangkit bagi pengguna. Pada prosesnya pengguna mengecek data jumlah nilai BPM, jika tidak berada diangka nomal (60100) selama kurun waktu yang relatif lama maka dapat melajutkan ke sistem pakar dengan memilih gejala apa saja yang terdapat pada form di system online Gambar 5. Data yang sudah di-input oleh pengguna maka system Variable Centered Intelligent Rule (VCIR)akan diolah dan hasilnya dapat dilihat secara online Gambar 6.

\section{UCAPAN TERIMA KASIH}

Terima kasih disampaikan kepada Universitas Muhammadiyah Surakarta, Direktorat Jenderal Pembelajaran dan Kemahasiswa (Belmawa), serta Kemenristekdikti yang telah memberikan pendanaan sehingga kegiatan penelitian ini bisa berjalan.

\section{DAFTAR PUSTAKA}

[1] Ahmed, dkk. 2015. Effective Diagnosis and Monitoring of Heart Disease (Jurnal Internasional IJSEIA). Zarqa : The Hashemite University.

[2] Depkes.(http://www.depkes.go.id/article/view/17073100005/ penyakitjantung-penyebab-kematian-tertinggi-kemenkes-ingatkan-cerdik-.html), diakses tanggal 23 Oktober 2017.

[3] Elektrologi.(http://elektrologi.kabarkita.org/sensor-detak-jantung) diakses tanggal 16 September 2016.

[4] GBD 2013, "Mortality and Causes of Death". 2014.

[5] Hartati , Sri. Iswanti, S. 2008. Sistem Pakar dan Pengembangannya. Yogyakarta: Graha Ilmu.

[6] Heruryanto, Hamdan. (2014). Sistem Pengukuran Detak Jantung Berbasis Mikrokontroller Atmage8535. Makassar : Tugas Akhir, Universitas Hasanuddin.

[7] Joel. 2012. Anatomy of The DIY Heart Rate Monitor. http://pulsesensor.myshopify.com/blogs/news/6326816anatomy-ofthediy-heart-rate-monitor diunduh 22.35 WIB tanggal 3 Juni 2018.

[8] Rachmawati, Nurul. (2010). Sistem Pakar untuk Mendiagnosa Penyakit Jantung dengan Menggunakan Metode Forward Chaining Berbasis Dekstop. Surakarta : Tugas Akhir, Universitas Muhammadiyah Surakarta.

[9] WHO.2015. "Cardiovascular Diseases". http://www.who.int/ cardiovascular_diseases/en/ diakses pada 2 juni 2018 pukul 04.25 WIB

[10] Zennifa, Fadilla. (2013). Prototipe Alat Deteksi Dini dan Mandiri Penyakit Jantung Menggunakan Sistem Pakar VCSIR, Arduino dan Handphone Android, Universitas Andalas. 